\title{
Uncommon Anatomic Predisposition to Myocardial Infarction: A Case of Coronary Artery Ectasia
}

\author{
Amre Ghazzal ${ }^{1}$, Laith Ali $^{1}$, Sohab Radwan ${ }^{1}$, Gauravpal S. Gill ${ }^{1}$, Hector M. Garcia-Garcia ${ }^{2}$ \\ 1. Internal Medicine, MedStar Washington Hospital Center, Washington, DC, USA 2. Cardiology, MedStar Washington \\ Hospital Center, Washington, DC, USA
}

Corresponding author: Amre Ghazzal, amrghazzal@hotmail.com

\begin{abstract}
Coronary artery ectasia (CAE) is a recognized cause of acute coronary syndrome (ACS), and can be associated with life-threatening complications, including thrombus formation with consequent distal coronary artery embolization. Several studies have demonstrated a higher incidence of cardiovascular adverse events and cardiac death in patients with CAE or coronary artery aneurysms compared to those without such abnormalities. Management of symptomatic CAE is similar to coronary artery disease (CAD), where guideline-directed medical therapy is indicated due to coexistence of CAD with acquired CAE. Percutaneous coronary intervention can be attempted; however, it is challenging, as it is associated with lower procedural success, higher rates of stent thrombosis, and repeat revascularization.
\end{abstract}

Received 06/12/2020

Review began 06/20/2020 Review ended 07/02/2020 Published 07/06/2020

๑ Copyright 2020

Ghazzal et al. This is an open access article distributed under the terms of the Creative Commons Attribution License CC-BY 4.0., which permits unrestricted use, distribution, and reproduction in any medium, provided the original author and source are credited.
Categories: Cardiology

Keywords: coronary artery ectasia, acute coronary syndrome

\section{Introduction}

Acute coronary syndrome (ACS) describes the range of myocardial ischemic states that include unstable angina, non-ST or ST segment elevation myocardial infarction. It is associated with substantial morbidity and mortality and places a large financial burden on the health care system. Coronary artery ectasia (CAE) is a recognized cause of ACS. It can be classified as congenital or acquired, with atherosclerosis being the most common cause of acquired CAE [1]. CAE presents commonly as stable angina; however, it can present as ACS [2]. It has also been associated with life-threatening complications, including thrombus formation with consequent distal coronary artery embolization, as well as shunt formation and rupture [3]. Managing CAE is similar to coronary artery disease (CAD); however, difficulties facing stent deployment in ectatic segments and complications associated with it pose a challenge for treating physicians.

\section{Case Presentation}

A 41-year-old male patient with a past medical history of hypertension and polysubstance use presents with chest pain and dyspnea on exertion of long duration. He was hemodynamically stable on presentation, and initial electrocardiogram demonstrated no significant ST-segment deviations, Q waves in leads III and aVF, T-wave inversion in lead III, and premature ventricular contractions (Figure 1); however cardiac biomarkers, namely cardiac troponin I, were elevated at $11.036 \mathrm{ng} / \mathrm{mL}$.

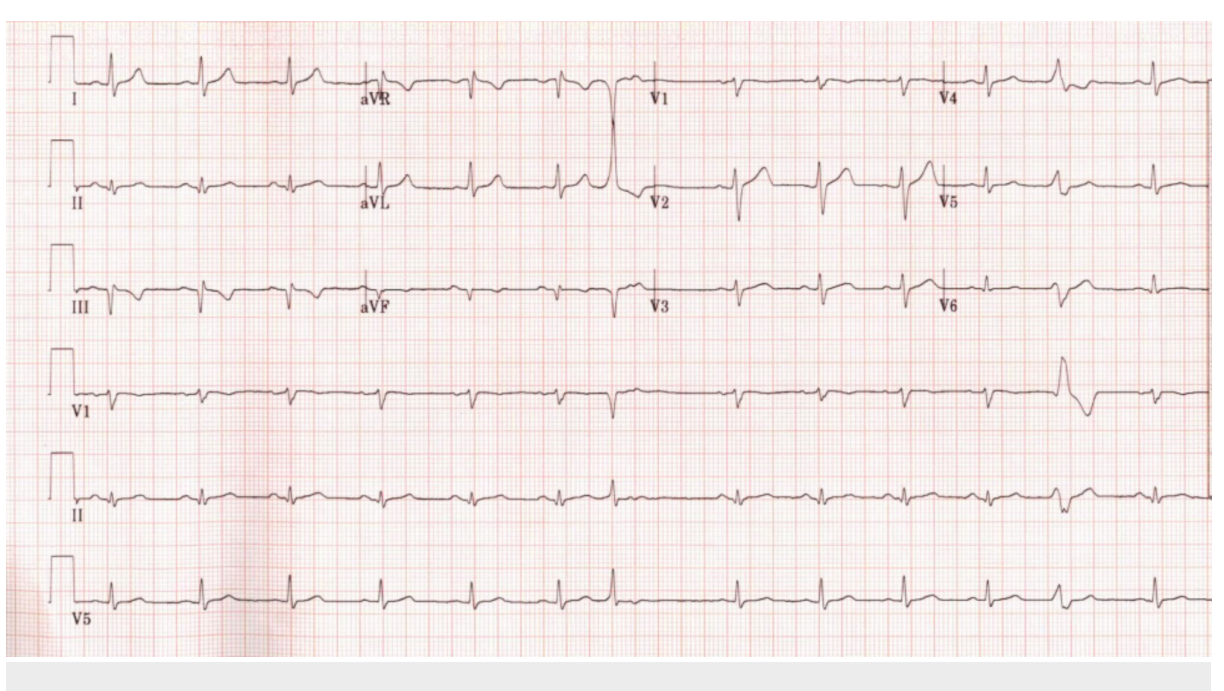

FIGURE 1: Electrocardiogram showing Q waves in leads III and aVF, T 


\section{Cureus}

wave inversion in lead III, and premature ventricular contractions.

He was medically managed with aspirin, nitroglycerin, and heparin, and admitted for further evaluation and management. Serial cardiac troponin I 6 hours later trended up to $20.10 \mathrm{ng} / \mathrm{mL}$ and due to persistent chest pain, he underwent coronary angiography which demonstrated a significantly ectatic right coronary (Figure $2 A$ ) and left anterior descending arteries (Figure $2 B$ ). There was also a thrombus in the right coronary (Figure $2 A$ ) artery posing a high risk for distal coronary embolization, stent placement was deferred, and thrombus aspiration was performed. Following the procedure, medical management with guideline-directed medical therapy was continued.

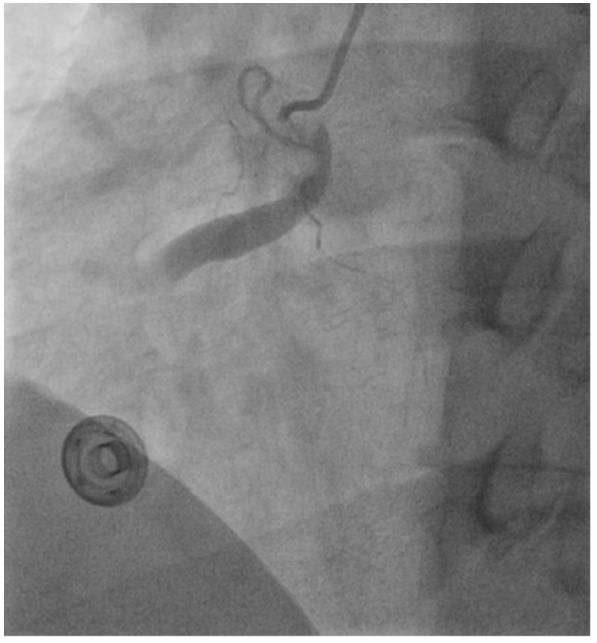

A

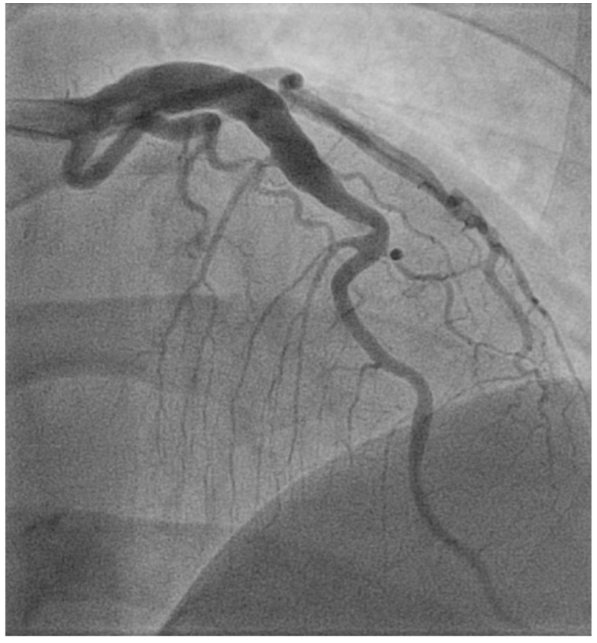

B

\section{FIGURE 2: (A) Ectatic right coronary artery with obstructive intramural thrombus. (B) Ectatic left anterior descending artery.}

\section{Discussion}

The terms "coronary artery ectasia" and "coronary artery aneurysm" have been used interchangeably; however, the term aneurysm describes a focal dilation of a coronary segment, while the term ectasia suggests a more diffuse aneurysmal lesion [4]. Several studies have demonstrated a higher incidence of cardiovascular adverse events and cardiac death in patients with CAE or coronary artery aneurysms as compared to those without such abnormalities $[5,6]$.

In general, management of CAE is similar to CAD, with few differences [1]. Antiplatelet therapy is indicated for CAE due to its coexistence with CAD. This is supported by literature showing that CAE is associated with increased platelet activation due to higher expression of P-selectin, beta-thromboglobulin, and platelet factor 4 as compared to controls with angiographically normal coronaries [3]. Anticoagulation with warfarin was suggested in one study to reduce the risk of thrombus formation [7]. Moreover, statins have been found to reduce expression of metalloproteinases contributing to CAE pathophysiology, while angiotensinconverting enzyme inhibitors (ACEi) were found to reduce progression of CAE due to its association with ACEi gene polymorphism $[8,9]$. Nitrates, on the other hand, should be avoided as they were shown to increase exercise-induced angina [10]. If refractory symptoms persist despite medical therapy, percutaneous coronary intervention can be attempted; however, it is challenging, as it is associated with lower procedural success, higher rates of stent thrombosis, and repeat revascularization [4,11-13]. Surgical options have demonstrated good outcomes in patients who fail medical and percutaneous management [14].

\section{Conclusions}

CAE is a recognized cause of ACS and is associated with life-threatening complications and management challenges. Currently, no guidelines are available for CAE management. Further large-scale clinical trials are needed to establish guidelines for managing CAE.

\section{Additional Information \\ Disclosures}

Human subjects: Consent was obtained by all participants in this study. Conflicts of interest: In compliance with the ICMJE uniform disclosure form, all authors declare the following: Payment/services 
info: All authors have declared that no financial support was received from any organization for the submitted work. Financial relationships: All authors have declared that they have no financial relationships at present or within the previous three years with any organizations that might have an interest in the submitted work. Other relationships: All authors have declared that there are no other relationships or activities that could appear to have influenced the submitted work.

\section{References}

1. Pahlavan PS, Niroomand F: Coronary artery aneurysm: a review. Clin Cardiol. 2006, 29:439-443. 10.1002/clc.4960291005

2. Hartnell GG, Parnell BM, Pridie RB: Coronary artery ectasia: its prevalence and clinical significance in 4993 patients. Heart. 1985, 54:392-395. 10.1136/hrt.54.4.392

3. Aboeata AS, Sontineni SP, Alla VM, Esterbrooks DJ: Coronary artery ectasia: current concepts and interventions. Front Biosci. 2012, 4:300-310.

4. Kawsara A, Núñez Gil IJ, Alqahtani F, Moreland J, Rihal CS, Alkhouli M: Management of coronary artery aneurysms. JACC Cardiovasc Interv. 2018, 11:1211-1223. 10.1016/j.jcin.2018.02.041

5. Warisawa T, Naganuma T, Tomizawa N, et al.: High prevalence of coronary artery events and non-coronary events in patients with coronary artery aneurysm in the observational group. Int J Cardiol Heart Vasc. 2016, 10:29-31. 10.1016/j.ijcha.2015.10.005

6. Doi T, Kataoka Y, Noguchi T, et al.: Coronary artery ectasia predicts future cardiac events in patients with acute myocardial infarction. Arterioscler Thromb Vasc Biol. 2017, 37:2350-2355. 10.1161/ATVBAHA.117.309683

7. Yasar AS, Erbay AR, Ayaz S, Turhan HD, Metin F, Ilkay E, Sabah I: Increased platelet activity in patients with isolated coronary artery ectasia. Coron Artery Dis. 2007, 18:451-454. 10.1097/MCA.0b013e3282a30665

8. Sorrell VL, Davis MJ, Bove AA: Current knowledge and significance of coronary artery ectasia: a chronologic review of the literature, recommendations for treatment, possible etiologies, and future considerations. Clin Cardiol. 1998, 21:157-160. 10.1002/clc.4960210304

9. Tengiz I, Ercan E, Aliyev E, Sekuri C, Duman C, Altuglu I : Elevated Levels of matrix metalloprotein-3 in patients with coronary aneurysm: a case control study. Curr Control Trials Cardiovasc Med. 2004, 5:10. 10.1186/1468-6708-5-10

10. Gülec S, Aras O, Atmaca Y, et al.: Deletion polymorphism of the angiotensin I converting enzyme gene is a potent risk factor for coronary artery ectasia. Heart. 2003, 89:213-214. 10.1136/heart.89.2.213

11. Joo HJ, Woong Yu C, Choi R, et al.: Clinical outcomes of patients with coronary artery aneurysm after the first generation drug-eluting stent implantation. Catheter Cardiovasc Interv. 2018, 92:E235-E245. 10.1002/ccd.27429

12. Iannopollo G, Ferlini M, Koziński M, et al.: Patient outcomes with STEMI caused by aneurysmal coronary artery disease and treated with primary PCI. J Am Coll Cardiol. 2017, 69:3006-3007. 10.1016/j.jacc.2017.04.030

13. Ipek G, Gungor B, Karatas MB, et al.: Risk factors and outcomes in patients with ectatic infarct-related artery who underwent primary percutaneous coronary intervention after ST elevated myocardial infarction. Catheter Cardiovasc Interv. 2016, 88:748-753. 10.1002/ccd.26553

14. Krüger D, Stierle U, Herrmann G, Simon R, Sheikhzadeh A: Exercise-induced myocardial ischemia in isolated coronary artery ectasias and aneurysms (“dilated coronopathy”). J Am Coll Cardiol. 1999, 34:14611470. 10.1016/s0735-1097(99)00375-7 